Check for updates

Cite this: RSC Adv., 2017, 7, 18976

Received 10th February 2017

Accepted 14th March 2017

DOI: 10.1039/c7ra01698k

rsc.li/rsc-advances

\section{Decolorization of Color Index Acid Orange 20 buffer solution using horseradish peroxidase immobilized on modified PAN-beads}

\author{
Zhu Yincan, Liu Yan, Guo Xueyong, Wu Qiao and Xu Xiaoping (DD *
}

\begin{abstract}
In the present work, horseradish peroxidase (HRP) is utilized to be immobilized onto polyacrylonitrile based beads (PAN-beads) for decolorization of Color Index (C. I.) Acid Orange 20 (AO20) in aqueous solution. Sodium hydroxide and hydrochloric acid were used to treat PAN-beads to obtain carboxyl groups, followed by being modified with ethanediamine to get more amino groups, and then were activated with glutaraldehyde. The enzyme was immobilized onto the activated beads by covalent crosslinking. Optimum factors for decolorization of $\mathrm{AO} 20$ were investigated both on free horseradish peroxidase (F$\mathrm{HRP}$ ) and immobilized horseradish peroxidase (I-HRP), including $\mathrm{pH}$ values, $\mathrm{H}_{2} \mathrm{O}_{2}$ amount, enzyme amount, temperature and so on. Under optimum conditions, percent decolorization was about $90 \%$ or 98\% respectively for F-HRP or I-HRP. A kinetic study showed that F-HRP possessed more affinity compared to I-HRP, but reusability experiments clarified that I-HRP was cost-efficient as about $90 \%$ decolorization was obtained after three cycles. The human normal hepatocytes cell line (L02 cell line) was utilized to assess cytotoxicity of metabolites, and the result was acceptable.
\end{abstract}

\section{Introduction}

In $1857, \mathrm{~W}$. H. Perkin invented the first synthetic dye called mauveine and put it into industrial production. Since then more and more synthetic dyes have appeared and have been widely used in industrial production sectors, such as textiles, paper, plastics, printing, leather, cosmetics, pharmaceuticals, and petrochemicals. But the wide usage of the various kinds of dyes in industries has led to discharging effluents containing dyes, rich in complex aromatic structures into the environment. There are more than $10^{5}$ kinds of commercially available dyes with over $8 \times 10^{5}$ metric tons of dye stuff leaked and discharged to industrial effluents, ${ }^{1}$ and nearly half of these are azoic dyes. ${ }^{2}$ The dyes are hardly degraded in the environment because oxidizing reagents, light and water can't damage their chemical structure. The chemical structure is characterized by the azo group $\mathrm{N}=\mathrm{N}$ which is a chromophore, associated with an auxochrome such as amine or hydroxyl groups. In natural degradation processes, microorganisms decolor azo dyes by reductive cleavage of azo bond under anaerobic conditions, leading to the formation of mutagenic aromatic amines, and these compounds become contaminants. ${ }^{3-6}$ When dye-containing effluents are released into the water bodies, dyes are visible pollutants at concentration of $0.005 \mathrm{mg} \mathrm{L}^{-1}, 7$ and the passage of light decreases along with increasing the chemical oxygen demand (COD). The azo dyes in the environment are toxic and

College of Chemistry, Fuzhou University, Fuzhou, 350108, P. R. China. E-mail: xu@ fzu.edu.cn potential carcinogens. ${ }^{8}$ Considering the harm to humans' health and environment, how to remove the synthetic dyes is always an important challenge and many researchers have reported their attempts, for example, $\mathrm{Li}$ and his co-workers used activated carbon as absorbent to adsorb Acid Orange $7^{9}$ and Gokce et al. found the $\mathrm{O}_{3}-\mathrm{H}_{2} \mathrm{O}_{2}-\mathrm{UV}$ process could dispose the wastewater of reactive dyeing of cotton fabric efficiently. ${ }^{\mathbf{1 0}}$ Though physical and chemical methods have been employed in many studies, ${ }^{11-13}$ they have some noticeable weaknesses, for instance, physical methods for color removal can't completely dispel recalcitrant azo dyes so it needs subsequent disposal, and chemical methods can degrade dyes but it needs to add other reagents which may be produce secondary pollution. As for activated sludge methods, it's not effective for dye removal. ${ }^{14-16}$

Based on the situation above, enzyme-based methods are more advantageous, which produce lower toxicity and make minimal impact on ecosystem. In addition, during enzymebased treatment process there is not need high energy requirements, difficult process control and rigorous $\mathrm{pH}$, temperature and ionic strength conditions. It is sufficient to use enzyme-based treatments alone as the toxic compounds can be transformed to less harmful compounds that means complete degradation is not necessary. ${ }^{\mathbf{1 7 - 2 0}}$

It is crucial to find a proper enzyme to degrade the dyes. It is reported that peroxidases and laccases from plants or fungi have the ability to oxidize dyes. ${ }^{21-23}$ Heme-containing peroxidases possess similar amino acid sequences and similar catalytic activities, but are slightly different in subsequent reaction 
products and substrate specificities. ${ }^{24}$ In the terms of decoloring or degrading the dyes, laccases and horseradish peroxidase have been extensively studied..$^{25-28}$

Horseradish peroxidase (HRP, EC 1.11.1.7) is an efficient, environmentally friendly and widely-researched biocatalystenzyme, which mainly exists in the roots of horseradish plants. HRP is a monomeric heme-obtaining glycoprotein (44 $\mathrm{kDa}$ ) having approximately $18 \% \mathrm{~N}$-linked oligosaccharides with function of two $\mathrm{Ca}^{2+}$ ions to maintain enzyme conformation..$^{29-31}$ In the presence of HRP, hydrogen peroxide $\left(\mathrm{H}_{2} \mathrm{O}_{2}\right)$ can oxidize aromatic compounds or azo dyes without high temperature or harsh chemical conditions. It has been proved by many researchers that phenolic compounds and textile dyes can be degraded or decolored by peroxidase, which has shown that HRP plays an important role in the removal of aqueous phenols and dyes. ${ }^{32-35}$ Compared to another effective biocatalyst-laccase (benzenediol: oxygen oxidoreductase, EC 1.10.3.2), HRP is more economical to produce, inactivates slowly, or acts on a wider variety of substrates.

Though enzyme-catalyzed process has more advantages in terms of handling effluents containing dyes, free enzymes have drawbacks of low stability, low production yield and unreusability. ${ }^{36}$ Immobilized enzymes on solid supports could overcome the limits above, which is capable of reusing immobilized enzymes and, as a result, reduces the overall cost of enzymatic waste. ${ }^{37,38}$ Immobilizing enzymes has many techniques, such as entrapment, encapsulation, self-immobilization and covalent binding of enzymes to solid support and so on, where covalent cross-linking gives enzyme more rigid structure and reduces protein unfolding, consequently makes enzymes significantly more stable. ${ }^{37}$ Polyacrylonitrile (PAN) are widely used as supporting materials of enzymes because of its good mechanical stability and its active nitrile groups. Different PAN modifications can be used to improve its properties as catalyst supports.

Our work was designed to immobilize horseradish peroxidase by covalent cross-linking with glutaraldehyde on polyacrylonitrile beads followed by the application of immobilized HRP for the elimination of AO20 from waste water. To establish an optimal operational process, some variables $\left(\mathrm{pH}, \mathrm{H}_{2} \mathrm{O}_{2}\right.$, contact time, temperature, dye concentration) involved in the oxidative process to remove $\mathrm{AO} 20$ from wastewater as well as the reusability experiment was evaluated particularly. The enzyme kinetic parameters $\left(K_{\mathrm{m}}\right.$ and $\left.V_{\max }\right)$ on the applied AO20 were also calculated. In addition, the toxicity of HRP-treated samples was evaluated using MTT cytotoxicity assay. MTT is the abbreviation of methylthiazolyldiphenyl-tetrazolium bromide, and the succino dehydrogenase in mitochondria of living cells can make exogenous MTT reduced to insoluable violet crystal - formazan.

\section{Experimental}

\subsection{Materials and reagents}

Polyacrylonitrile (PAN) was purchased from Heowns Biochem Technologies LLC, China. C. I. Acid Orange (shown in Table 1), hydrogen peroxide $\left(\mathrm{H}_{2} \mathrm{O}_{2}\right)$, sodium hydroxide $(\mathrm{NaOH})$, hydrochloric acid ( $\mathrm{HCl})$, phosphoric acid $\left(\mathrm{H}_{3} \mathrm{PO}_{4}\right)$, ethylenediamine, $N, N$-dimethylformamide (DMF), glutaraldehyde, guaiacol, coomassie brilliant blue G-250, ethanol, sodium dihydrogen phosphate and disodium hydrogen phosphate were all obtained from Sinopharm Chemical Reagents CO., Ltd. Horseradish peroxidase (HRP) ((EC 1.11.1.7), >300 $\mathrm{U} \mathrm{mg}^{-1}$ ) and bovine serum albumin (BSA) were purchased from Shanghai SANGON Biological Engineering Co., Ltd, China. The aforementioned chemicals were of analytical grade and were used without further purification during follow-up study. Solutions were confected with distilled water (prepared by Fuzhou University). In this experiment, $\mathrm{AO} 20$ buffer solution was used to simulate industrial wastewater containing an azo dye.

\subsection{Preparation of PAN-based beads}

The preparation of PAN-based beads was performed as follows. $2 \mathrm{~g}$ polyacrylonitrile was dissolved in $23 \mathrm{~g}$ DMF and was kept in constant mechanical stirring until the solution became a homogenous gel. The PAN-based beads were prepared by onestep extrusion similar to that described by Nigma. ${ }^{39}$ With the help of a peristaltic pump, the homogenous gel was dropped through a silicon tube into a beaker containing $200 \mathrm{~mL}$ of distilled water. $10 \mathrm{~cm}$ dropping height was chose to avoid the droplets sticking together and trailing. The obtained PAN-based beads were spherical beads with the same size, and the diameter of beads was about $3 \mathrm{~mm}$. Then these beads were washed three times using distilled water. Afterwards the PAN-beads were filtrated and stored in the phosphate buffer $(\mathrm{pH}$ 7.4) under $4{ }^{\circ} \mathrm{C}$ for further utilization.

\subsection{Modifications of PAN-beads}

This step of the modifications of PAN-based beads was aimed to transform the nitrile group in PAN into amino or introduce amino groups so that these PAN-based beads could crosslinked with glutaraldehyde. Firstly, these beads were immersed in 100 $\mathrm{mL}$ of $12 \%(\mathrm{w}) \mathrm{NaOH}$ aqueous solution for $1 \mathrm{~h}$ at $50^{\circ} \mathrm{C}$, and the nitrile groups in PAN were transformed into sodium carboxylate groups. Secondly, they were washed with deionized water and placed in $1 \mathrm{~mol} \mathrm{~L}^{-1} \mathrm{HCl}$ aqueous solution at room temperature for $2 \mathrm{~h},{ }^{40}$ and the sodium carboxylate groups were transformed into carboxylic groups. Thirdly, the beads were immersed in $10 \%(\mathrm{v} / \mathrm{v})$ solution of ethylenediamine for $1 \mathrm{~h}$ at room temperature, a large number of amino groups were introduced and $\mathrm{C}=\mathrm{N}$ was formed at the moment. Lastly, the obtained beads were washed thoroughly with deionized water to remove the unreacted ethylenediamine and then rinsed with phosphate buffer.

\subsection{Glutaraldehyde activation and horseradish peroxidase immobilization}

The modified beads were immersed in $10 \%(\mathrm{v} / \mathrm{v})$ solution of glutaraldehyde for $60 \mathrm{~min}$ at $4{ }^{\circ} \mathrm{C}$. Then, the beads were thoroughly washed with distilled water and phosphate buffer. After that the beads were kept in the solution of horseradish peroxidase $\left(1 \mathrm{mg} \mathrm{mL}^{-1}\right)$ for $24 \mathrm{~h}$ at $4{ }^{\circ} \mathrm{C}$. Finally, the resulting beads were washed with distilled water thoroughly once again. After immobilization, the color of the initial white beads were turned into brownish red, but almost no changes in the sizes of the 
Table 1 Characteristics of C. I. Acid Orange 20

\begin{tabular}{|c|c|}
\hline Properties & Value \\
\hline $\begin{array}{l}\text { Molecular formula } \\
\text { CAS }\end{array}$ & $\begin{array}{l}\mathrm{C}_{16} \mathrm{H}_{11} \mathrm{~N}_{2} \mathrm{NaO}_{4} \mathrm{~S} \\
523-44-4\end{array}$ \\
\hline $\begin{array}{l}\text { Molecular weight } \\
\text { Chromophore } \\
\lambda_{\max }\end{array}$ & $\begin{array}{l}350.32 \\
\text { Diazo } \\
488 \mathrm{~nm}\end{array}$ \\
\hline
\end{tabular}

beads. The immobilized beads were stored in phosphate buffer (0.1 M, pH 7.0) at $4{ }^{\circ} \mathrm{C}$.

\subsection{Characterization of the beads}

2.5.1 Scanning electron microscopy (SEM). Before scanning the initial/immobilized beads were dried and sputtercoated with nanogold under vacuum for electrical conductivity. SEM was applied to characterise the surface morphology of initial/modified/immobilized beads, and the changes on the surface of PAN-beads were observed clearly.

2.5.2 Energy dispersive spectrometer (EDS). SEM-EDS is one of the most widely used microscopic analysis instrument. On the basis of SEM, by combination with EDS, microchemicalanalysis of the two kinds of beads was performed.

2.5.3 Fourier transform infrared spectroscopy-attenuated total reflection spectra (FTIR-ATR). FTIR was conducted to characterize the surface chemical groups of the initial/ modified/immobilized beads. ${ }^{41}$ FTIR-ATR was recorded using an attenuated total reflectance technique with a spectrometer in the range of $4000-400 \mathrm{~cm}^{-1}$.

\subsection{Measuring methods of protein loading and horseradish peroxidase activity}

The total amount of protein bound with the modified beads was determined by the method of Coomassie light blue staining assay (also called Bradford assay). ${ }^{42}$ The amount of immobilized enzyme were obtained by subtracting the amount of enzyme determined in the residual solutions and washings from the total amount of protein. The tested solution was determined at $595 \mathrm{~nm}$. A calibration curve was obtained using BSA as a standard. ${ }^{43}$

The activity of HRP denoted as the decomposition rate of $\mathrm{H}_{2} \mathrm{O}_{2}$ by HRP, with guaiacol as hydrogen donor, was determined colorimetrically by measuring the rate of color development at $470 \mathrm{~nm}$ and at $25{ }^{\circ} \mathrm{C}^{.44}$ In this assay, HRP needed to be dissolved in $0.1 \mathrm{M}$ sodium phosphate buffer at $\mathrm{pH}$ 6.0. The reaction mixture was prepared as follows: $0.1 \mathrm{M}$ sodium phosphate buffer ( $\mathrm{pH}$ 6.0) was placed in a $50 \mathrm{~mL}$ beaker, adding $28 \mu \mathrm{L}$ guaiacol, and stirred on the heated magnetic stirrer until guaiacol was completely dissolved. When the before-mentioned solution cooled, $19 \mu \mathrm{L} 30 \%(\mathrm{v} / \mathrm{v}) \mathrm{H}_{2} \mathrm{O}_{2}$ was added and mixed uniformly and then stored in the refrigerator. When measuring the absorbance, $3 \mathrm{~mL}$ reaction mixture and $1 \mathrm{~mL} \mathrm{HRP} \mathrm{solution}(1 \mathrm{~mL} 0.1 \mathrm{M}$ sodium phosphate buffer ( $\mathrm{pH}$ 6.0) for the control group) would be mixed together and then measured at $470 \mathrm{~nm}$ every $30 \mathrm{~s}$ for 5 min. The activity of immobilized HRP was calculated by subtracting the amount of activity determined in the residual solutions and washings from the total amount of activity.

\subsection{Optimization of AO20 oxidation by immobilized HRP (I- HRP) and free HRP (F-HRP)}

The assay was conducted to obtain an optimum condition for the removal of $\mathrm{AO} 20$ in aqueous phase using PAN-based immobilized HRP. Some crucial factors vastly impacted the removal of $\mathrm{AO} 20: \mathrm{pH}$ value, contact time, the amount of immobilized HRP, $\mathrm{H}_{2} \mathrm{O}_{2}$ amount, dye concentration, temperature. To obtain the optimization of AO20 oxidation by immobilized HRP must obtain the optimum values of abovementioned factors. The experiments were carried out equipped with a constant temperature oscillation incubator. The effects of $\mathrm{pH}$ on the dye removal ability of the immobilized and free enzymes were determined using the $\mathrm{pH}$ range 3.0-10.0 at $25{ }^{\circ} \mathrm{C}$, in more detail, the percent dye removal for F-HRP was determined in buffer solutions of $\mathrm{pH} 3,5,6.5,7,7.5,8,9$ and 10, and the percent dye removal for I-HRP was determined in buffer solutions of $\mathrm{pH} 3,4,5,6,6.5,7,8,9$ and 10 . The effects of contact time were determined using the time range 10-150 min for I-HRP and the samples were withdrawn every twenty or thirty minutes, while the time range for F-HRP was 10-100 min and the samples were tested every ten or twenty minutes. The effects of $\mathrm{H}_{2} \mathrm{O}_{2}$ amount for I-HRP and F-HRP were determined using the range $0.3-1.6 \mu \mathrm{mol}$ with an interval of $0.1 \mu \mathrm{mol}$ or $0.2 \mu \mathrm{mol}$. The effect of the amount of immobilized enzyme was determined using the range $0.2-8 \mathrm{mg}$ (10 $\mathrm{mg}$ immobilized enzyme equaled to $1 \mathrm{~g}$ PAN-based beads) with an interval of $1 \mathrm{mg}$, while the effect of free enzyme dosage was designed to use the range 10-100 $\mu \mathrm{g}$ and the dye removal was determined respectively when there was 1, 5, 10, 50 and $100 \mu \mathrm{g}$ free enzyme in the dye 
solution. The effects of the dye concentration on both free and immobilized enzyme were determined at the range 50-300 $\mathrm{mg}$ $\mathrm{L}^{-1}$ with an interval of $50 \mathrm{mg} \mathrm{L}^{-1}$. The effects of the temperature were determined at the range $20-40{ }^{\circ} \mathrm{C}$ with an interval of $5{ }^{\circ} \mathrm{C}$. Every obtained optimum value was applied for other tests of influencing factors and these experiments were conducted in triplicate.

\subsection{The reusability of PAN-based immobilized HRP}

The reusability of PAN-based immobilized beads was measured following the steps below. After each cycle of reaction, the enzyme immobilized beads were removed and washed with phosphate buffer $(0.1 \mathrm{M}, \mathrm{pH}$ 7.0) to remove any residual substrate adhering to immobilized beads. After that, the immobilized beads were transferred into fresh dye solution and percent removal was determined. The percent removal in every cycle was used to indicate immobilized enzyme activity. All the experiments were conducted in triplicate.

\subsection{Cytotoxicity test}

2.9.1 Cell culture. The comparison between the cytotoxicity of the raw dye solution and that of the solution after enzyme treatment were tested on L02 (human normal hepatocytes) cell line obtained from Shanghai Institutes for Biological Sciences (Chinese Academy of Sciences) and conserved in laboratory at $-80{ }^{\circ} \mathrm{C}$. This kind of cell line was cultivated in Dulbecco's Modified Eagle's Medium (DMEM). The medium contained 10\% Foetal Bovine Serum (FBS). Penicillin $\left(100 \mathrm{U} \mathrm{mL}^{-1}\right)$ and streptomycin $\left(100 \mu \mathrm{g} \mathrm{mL} \mathrm{m}^{-1}\right)$ was added in the medium as supplement. Cells were cultivated in a humidified atmosphere of $5 \% \mathrm{CO}_{2}$ at $37{ }^{\circ} \mathrm{C} .300 \mathrm{mg} \mathrm{L}{ }^{-1}$ dye solution no-treated and treated were prepared and produced as stock solution used in vitro tests.

2.9.2 MTT assay. Microculture tetrazolium (MTT) assay is aimed to judge cell cytotoxicity by measuring cell viability. The cells cultured before were trypsinized and seeded in 96-well plates at the density of $1 \times 10^{5}$ cells per well respectively and then subjected to $24 \mathrm{~h}$ incubation. After this step, raw and treated AO20 diluted to different concentrations were added in every well in the plates and the cells were exposed for $2 \mathrm{~h}$. The control cells received only medium with phosphate buffer ( $\mathrm{pH}$ 7.4). After that, $100 \mu \mathrm{L}$ serum-free medium containing $2.5 \mathrm{mg} \mathrm{mL}^{-1}$ MTT solution were added in all the wells followed by incubation for $4 \mathrm{~h}$ in the same conditions of $37^{\circ} \mathrm{C}$ and $5 \% \mathrm{CO}_{2}$ atmosphere. Then 150 $\mu \mathrm{L}$ DMSO were added in each well to dissolve the water-insoluble precipitate, which were blue formazan. The absorbance was measured at $570 \mathrm{~nm}$ using a microplate reader (Tecan Infinite M200pro) and the relative cell viability (\%) was calculated by $\left(\left[A_{570}\right]_{\text {test }}\left[\left[A_{570}\right]_{\text {control }}\right) \times 100 \%\right.$. All specimens were placed in six wells to obtain statistically reliable results and control specimens were normalized to $100 \%$ viable cells.

\section{Results and discussion}

\subsection{Preparation of HRP modified PAN-beads}

The preparation of HRP modified PAN-beads were began with the conversion of the nitrile groups on the surface of the PAN- beads to carboxyl groups treated in $\mathrm{NaOH}$ solution and $\mathrm{HCl}$ solution and the color of these beads became yellow. Then the carboxylic PAN-beads were rinsed in ethanediamine solution and the color became flavescens, which indicated a certain chemical change on these beads in a way. The aforementioned PAN-beads were crosslinked in glutaraldehyde solution and then covalent bound with HRP and the color of these beads ultimately became brown. The whole process was shown as Fig. 1.

\subsection{Characterization of modified PAN-beads}

3.2.1 FTIR-ATR analysis. The surface of the initial beads have nitrile groups $(-\mathrm{CN})$ which provide modification with possibility. Those nitrile groups were modified with $\mathrm{NaOH}$ and $\mathrm{HCl}$ to form carboxylic group. The modified beads were aminated using ethylenediamine, then activated with glutaraldehyde. This kind of cross-linked modified PAN-beads can react with the amino groups creating imine groups on the surface of beads. From this mechanism, the horseradish peroxidase was covalently immobilized on the PAN-based beads.

FT-IR spectra of beads of every stage during immobilization process were depicted in Fig. 2 to verify the whole changes on the surface of PAN-beads. Line (a) represents initial beads, the absorption peak at $2242 \mathrm{~cm}^{-1}$ is attributed to the stretching vibrations band of nitrile groups (-CN). The bands at $2934 \mathrm{~cm}^{-1}$ and $1452 \mathrm{~cm}^{-1}$ are attributed by stretching and bending vibration bands of methylene $\left(-\mathrm{CH}_{2}-\right)$ on the bead surface. Line (b) represents carboxylated PAN formed by using $\mathrm{NaOH}$ and $\mathrm{HCl}$ to dispose initial PAN. The peaks at $3129 \mathrm{~cm}^{-1}$ and $1687 \mathrm{~cm}^{-1}$ can be ascribed to the presence of $\mathrm{O}-\mathrm{H}$ bond and $\mathrm{C}=\mathrm{O}$ bond of carboxylic acids, and both the two peaks verify the presence of -COOH. Line (c) is representative of cross-linked PAN-beads formed by using ethylenediamine and glutaraldehyde to treat carboxylated PAN. The peak of $3379 \mathrm{~cm}^{-1}$ is attributed to stretching vibrations band of $-\mathrm{NH}$ because of reaction with ethylenediamine on the bead surface. The absorption peak of $1632 \mathrm{~cm}^{-1}$ is ascribed to $\mathrm{C}=\mathrm{N}$ formed by the reaction between $-\mathrm{CHO}$ and $-\mathrm{NH}_{2}$. Line (d) shows the spectra of immobilization HRP (I-HRP). Line (d) is similar to line (a), because there is a same reaction happening between $-\mathrm{CHO}$ and $-\mathrm{NH}_{2}$ during this course and it can't testify the presence of HRP obviously, so undermentioned EDS analysis is to add to prove it.

3.2.2 SEM observation. SEM is usually used to analyse surface morphology of substance. Fig. 3 showed the results of the surface morphology of PAN-beads during modification. Fig. 3a was representative of PAN-beads untreated with chemicals, and its surface was rough and irregular. Fig. $3 \mathrm{~b}$ referred to crosslinked PAN-beads, which underwent disposal with $\mathrm{NaOH}$, $\mathrm{HCl}$, ethylenediamine and glutaraldehyde successively, and some parts of the surface were rougher compared to initial PANbeads because of erosion while other parts of the surface were smoother. Fig. 3c stood for PAN-beads modified by HRP, and its surface was smoother than Fig. $3 \mathrm{a}$ and $\mathrm{b}$ and almost had no irregularity.

3.2.3 EDS analysis. EDS (Energy Dispersive Spectrometer) was used to analysis the changes between initial and 


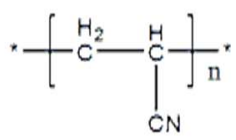

polyacrylonitrile (PAN)

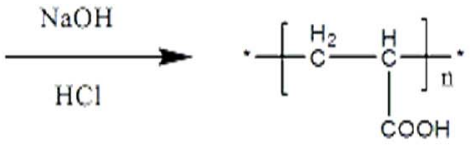

PAN-COOH<smiles>NCCCCCN</smiles><smiles>CC(CCCC(C)(C)C)C(C)CC(=O)NCCN</smiles>

Activated PAN-beads

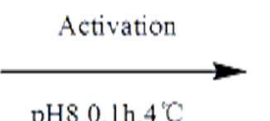<smiles>CC(C)(C)CC(C=O)C(C)(C)C</smiles><smiles>O=CCCC/C=N\CCNC=O</smiles>

Activated PAN-beads
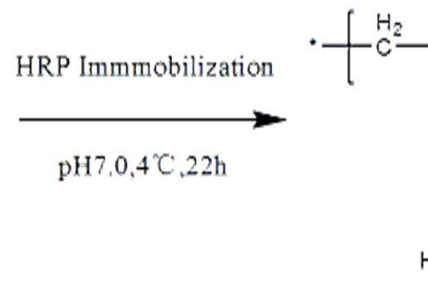<smiles>C=C(CC(C)C)NCC1CC1</smiles><smiles>CC(C)(C)C(=O)C1(C)CCCCCC1</smiles>

HRP immobilized PAN-beads

Fig. 1 The modification process of PAN-beads.

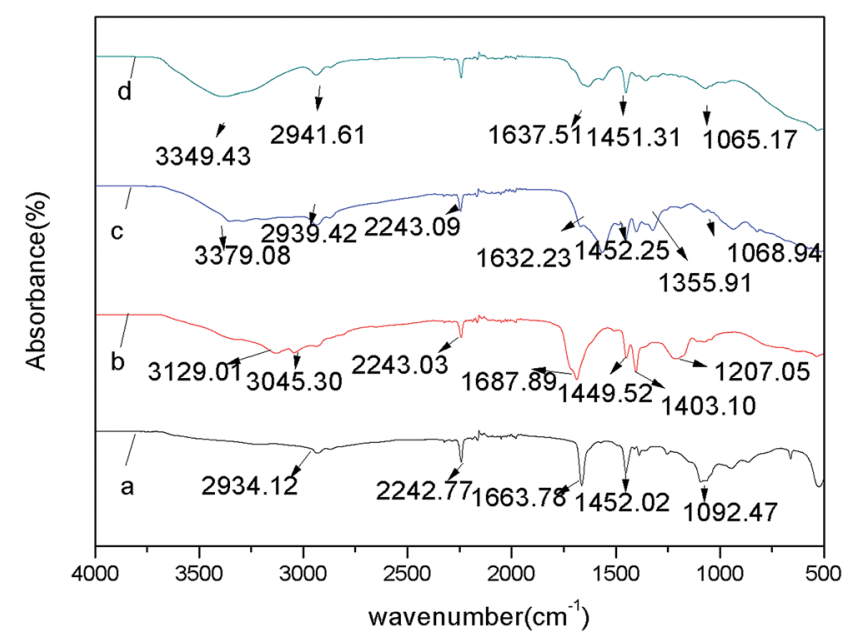

Fig. 2 ATR-FTIR spectrum during the immobilization process (a: initial PAN; b: carboxylated PAN; c: carboxylated PAN treated with ethylenediamine and glutaraldehyde successively; $d$ : immobilization PAN). immobilized beads in this work. Fig. 4 presents different EDS spectra of beads. ${ }^{45}$ The results showed that the element $\mathrm{N}$ increased by approximately $8 \mathrm{wt} \%$, followed by the increase of element $\mathrm{C}$ (less than $7 \mathrm{wt} \%$ ) in the area of the initial beads in Fig. 4(A), compared to the enzyme immobilized beads in Fig. 4(B). Moreover, the EDS indicated that S and Fe elements were not existed on the initial beads, but it could be noticed the presence of $\mathrm{S}$ and Fe peaks in the enzyme immobilized beads. $\mathrm{S}$ and $\mathrm{Fe}$ elements accounted for $0.68 \mathrm{wt} \%$ and $0.25 \mathrm{wt} \%$ respectively, which could certify the appearance of horseradish peroxidase on the beads. These analysis showed that the horseradish peroxidase was successfully immobilized onto the beads.

\subsection{The amount of HRP onto the activated PAN-beads and the activity of immobilized beads}

The biocatalytic performance was evaluated regarding the immobilization amount (IA) and relative activity (RA). Eqn (2) was used to calculate the amount of enzyme immobilized. The protein standard curve was obtained by Bradford assay and the 

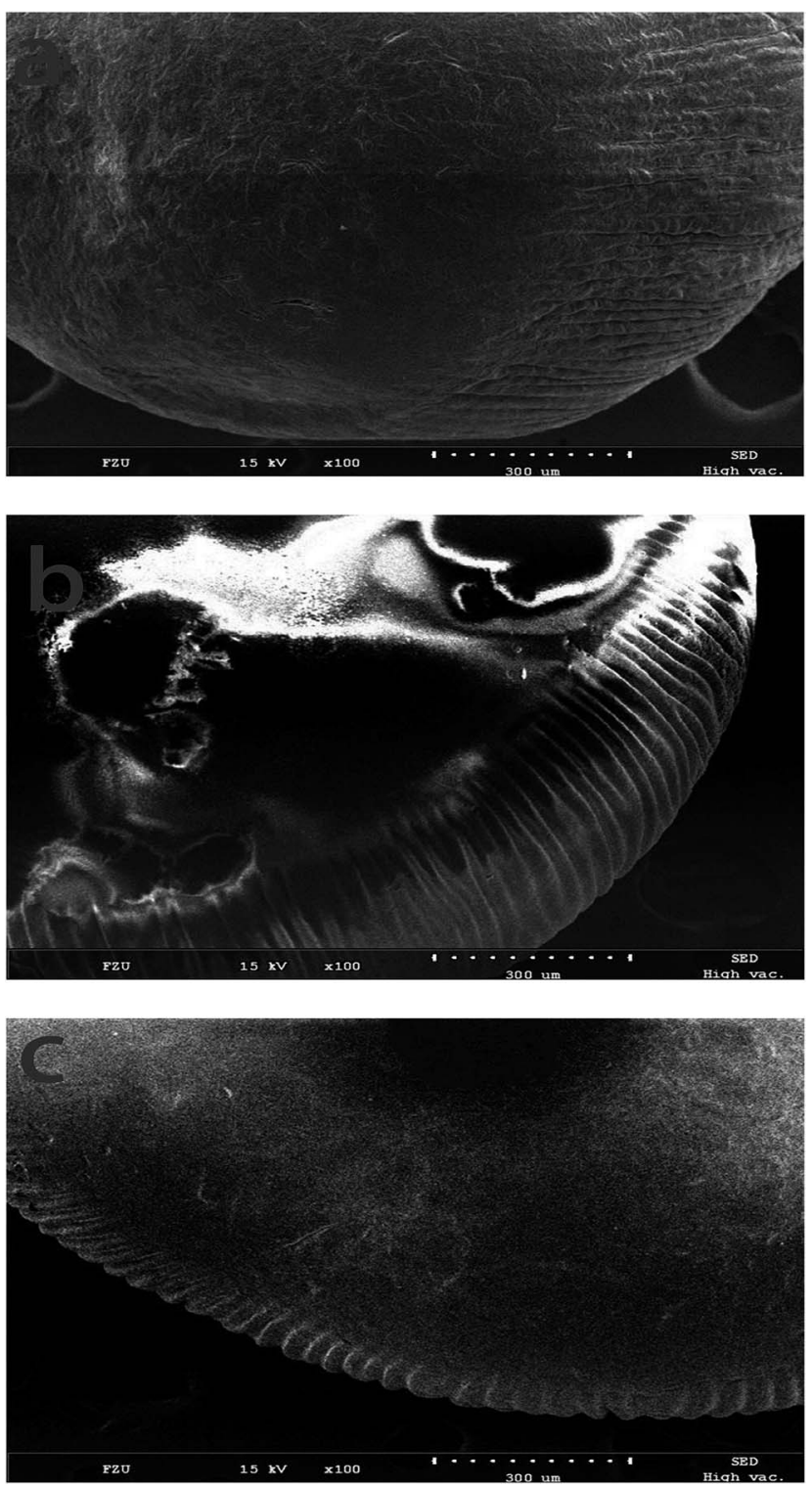

Fig. 3 SEM of PAN-beads at different stage (a: SEM of initial PANbeads; b: SEM of crosslinked PAN-beads; c: SEM of PAN-beads modified with HRP).

fitting equation was described as eqn (1), which was used to count the amount of enzyme in solution. Eqn (3) was used to count relative activity (RA).

$$
A=0.0062 C+0.2364\left(R^{2}=0.9996\right)
$$

where $A$ is absorbance value, $C$ is the concentration of the protein, and $R$ is fitting correlation coefficient.

IA = enzyme added - enzyme in residual solution - enzyme in washings

$\operatorname{RA}(\%)=\frac{\text { specific activity of immobilized HRP }\left(\mathrm{U} \mathrm{mg}_{\text {protein }}{ }^{-1}\right)}{\text { specific activity of free } \operatorname{HRP}\left(\mathrm{U} \mathrm{mg}_{\text {protein }}{ }^{-1}\right)}$ $\times 100$
The results were that IA was $10.0 \mathrm{mg} \mathrm{g}^{-1}$ and RA was $67 \%$.

\subsection{Kinetics parameters of free and immobilized horseradish peroxidase}

To obtain the kinetics parameters of both free and immobilized enzyme, five kinds of concentrations of dye solution were employed for our kinetics experiment. The linear parts of their curves were depicted in Fig. 5 to calculate the kinetics parameters. Kinetics parameters of free and immobilized horseradish peroxidase towards AO20 were elucidated in Table $2 . K_{\mathrm{m}}$ value of free horseradish peroxidase was $0.288 \mathrm{mM}$ and that of immobilized horseradish peroxidase was $1.458 \mathrm{mM}$, which was 5 folds to free horseradish peroxidase. $V_{\max }$ of immobilized horseradish peroxidase was $14.2 \mu \mathrm{M} \min ^{-1}$ and that of free horseradish peroxidase was $89.7 \mu \mathrm{M} \mathrm{min}{ }^{-1}$, which was about 6 folds to immobilized horseradish peroxidase. The higher $K_{\mathrm{m}}$ value of immobilized horseradish peroxidase towards the applied dye means lower affinity of immobilized horseradish peroxidase for the applied dye compared to free ones. At the same time, the lower $V_{\max }$ value also means lower affinity, corresponding with $K_{\mathrm{m}}$ value. Some reasons explaining the difference in behavior of the free and immobilized horseradish peroxidase are listed here: immobilized enzyme is located in a quite different microenvironment from that of free enzyme in the bulk solution. Steric hindrance and diffusional limitation result in less chance to react with active sites of immobilized horseradish peroxidase due to the change of enzyme conformation.

\subsection{The optimum conditions to treat C. I. Acid Orange 20 (AO20) solution}

3.5.1 Effect of $\mathbf{p H}$. The effect of $\mathrm{pH}$ was investigated on both free horseradish peroxidase (F-HRP) and immobilized horseradish peroxidase (I-HRP) for disposal of AO20 solution when other conditions were at optimal state. For F-HRP, $50 \mu \mathrm{L}$ free enzyme were added in $50 \mathrm{mg} \mathrm{L}^{-1} \mathrm{AO} 20$ solution containing $1.0 \mu \mathrm{mol} \mathrm{H}_{2} \mathrm{O}_{2}$ at $25^{\circ} \mathrm{C}$ under agitation $100 \mathrm{rpm}$ for $40 \mathrm{~min}$ (the volume of the whole system was $5 \mathrm{~mL}$ ). For I-HRP, $0.6 \mathrm{~g}$ PANbeads were added in $50 \mathrm{mg} \mathrm{L}{ }^{-1}$ AO20 solution containing 1.2 $\mu \mathrm{mol} \mathrm{H}_{2} \mathrm{O}_{2}$ at $30{ }^{\circ} \mathrm{C}$ under agitation $100 \mathrm{rpm}$ for $90 \mathrm{~min}$ (the volume of the whole system was $5 \mathrm{~mL}$ ). The $\mathrm{pH}$ dependent of free and immobilized enzyme on disposal of $\mathrm{AO} 20$ in the range of $\mathrm{pH}$ from 3 to 10 was studied. The effect of $\mathrm{pH}$ on decolorization for both F-HRP (free horseradish peroxidase) and I-HRP (immobilized horseradish peroxidase) is shown as Fig. 6.

The optimum $89.89 \%$ of $\mathrm{AO} 20$ decolorization was obtained with neutral medium (buffer $\mathrm{pH}$ 7.0) for F-HRP. Dye removal efficiency increased from $\mathrm{pH} 3.0$ to 7.0 , followed by a decrease down to about $75 \%$ from $\mathrm{pH} 7.0$ to 10.0 . The reason could be that $\mathrm{pH} 7.0$ may provide F-HRP with appropriate environment, where F-HRP possessed a higher activity so that dye removal efficiency was high. On the other hand, for I-HRP, about $97 \%$ of AO20 was removed with light acidulous medium (buffer $\mathrm{pH}$ 6.5). And the percent decolorization of I-HRP was higher over a wide range of varying $\mathrm{p} K_{\mathrm{a}}$ value compared to F-HRP, which could be attributed to the bared activated centers of enzyme 

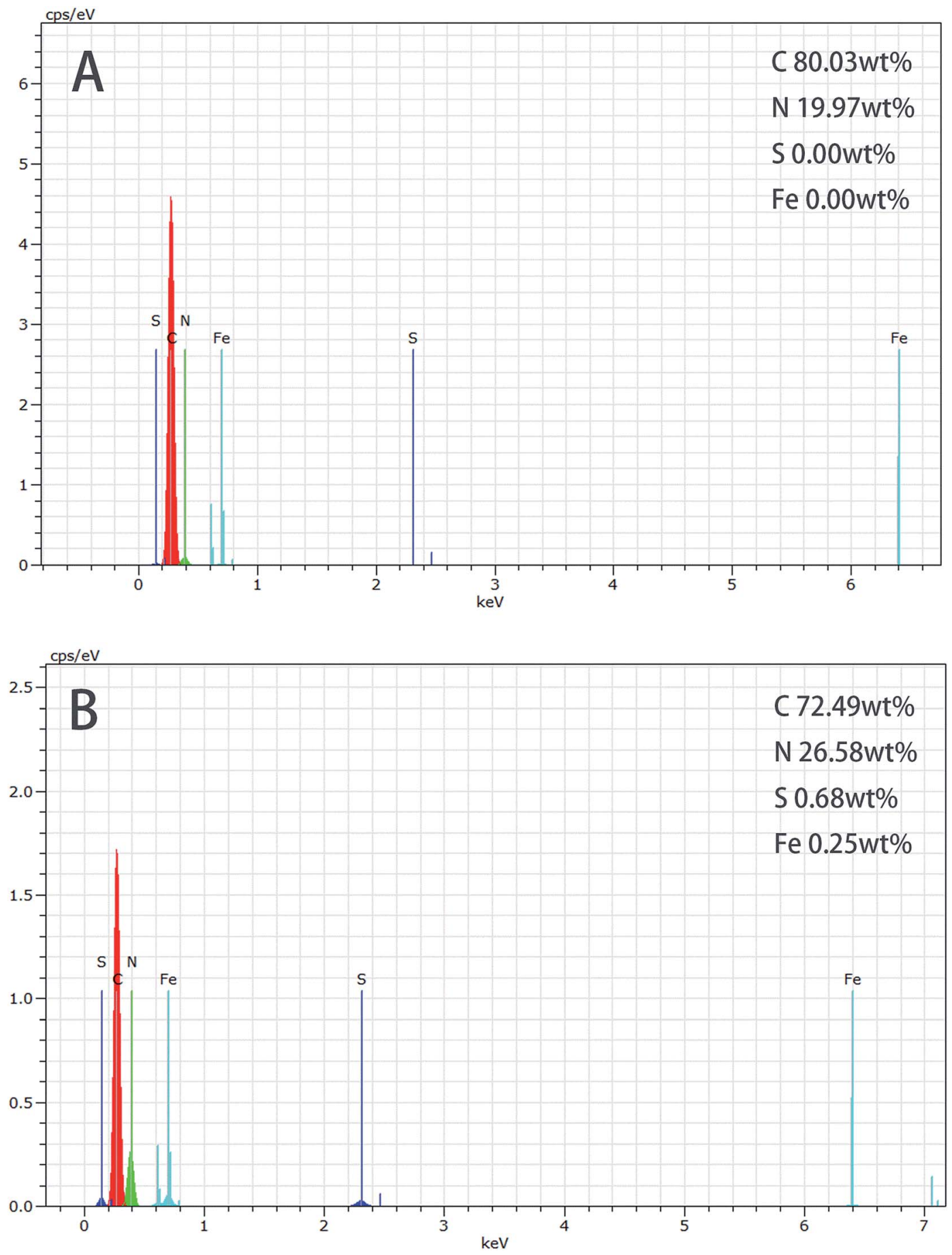

Fig. 4 EDS spectra photographs of: (A) initial beads; (B) immobilized beads.

because of the changes in the structure of I-HRP. In addition, $\mathrm{pH}$ could influence the form of dye in water which could impact degradation, and we could clearly know I-HRP behaved better at wide range of $\mathrm{pH}$ from Fig. 6 .

3.5.2 Effect of $\mathrm{H}_{2} \mathrm{O}_{2}$ amount. The effects of $\mathrm{H}_{2} \mathrm{O}_{2}$ were observed at a range of different $\mathrm{H}_{2} \mathrm{O}_{2}$ amount from $0.3 \mu \mathrm{mol}$ to $1.6 \mu \mathrm{mol}$ in a system of $5 \mathrm{~mL}$ volume. For F-HRP, with the condition of different $\mathrm{H}_{2} \mathrm{O}_{2}$ amount, $50 \mu \mathrm{L}$ free enzyme were added in $50 \mathrm{mg} \mathrm{L}^{-1} \mathrm{AO} 20$ solution $\left(\mathrm{pH} \mathrm{7.0)}\right.$ at $25{ }^{\circ} \mathrm{C}$ under agitation $100 \mathrm{rpm}$ for $40 \mathrm{~min}$ (the volume of the whole system was $5 \mathrm{~mL}$ ), and the dye removal reached its peak at $1.0 \mu \mathrm{mol}$ $\mathrm{H}_{2} \mathrm{O}_{2}$. After that, the dye removal decreased with increasing the amount of $\mathrm{H}_{2} \mathrm{O}_{2}$. For I-HRP, with the condition of different $\mathrm{H}_{2} \mathrm{O}_{2}$ amount, $0.6 \mathrm{~g}$ PAN-beads were added in $50 \mathrm{mg} \mathrm{L}^{-1} \mathrm{AO} 20$ solution (pH 6.5) at $25{ }^{\circ} \mathrm{C}$ under agitation $100 \mathrm{rpm}$ for $90 \mathrm{~min}$ (the volume of the whole system was $5 \mathrm{~mL}$ ), and the dye removal was with its maximum at $1.2 \mu \mathrm{mol} \mathrm{H}_{2} \mathrm{O}_{2}$. After that, the same as F-HRP, the efficiency of dye removal decreased along with the 


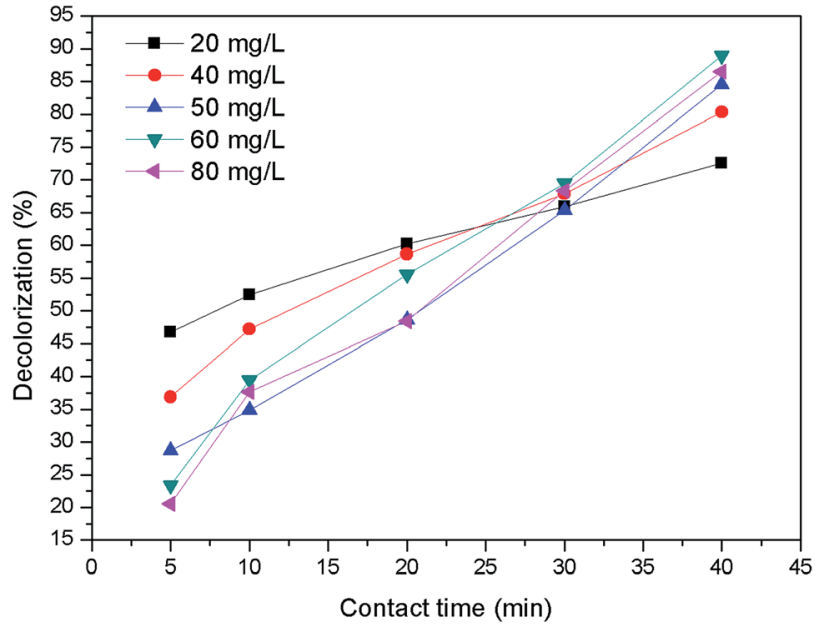

a: for free horseradish peroxidase

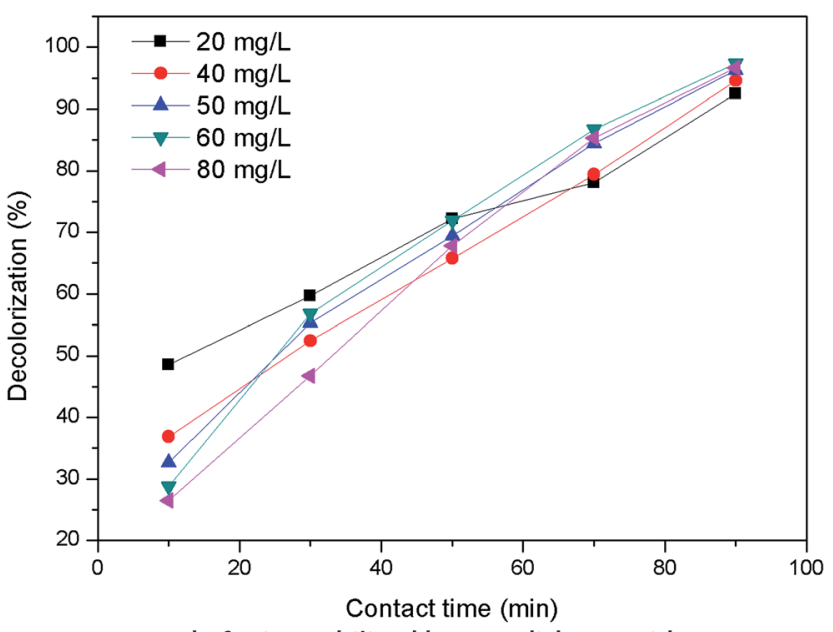

b: for immobilized horseradish peroxidase

Fig. 5 The relation between the percent dye removal and contact time for five kinds of concentrations of dye solution.

Table 2 Michaelis-Menten parameters of the free and immobilized horseradish peroxidase

\begin{tabular}{lll}
\hline Horseradish peroxidase & $K_{\mathrm{m}}(\mathrm{mM})$ & $V_{\max }\left(\mu \mathrm{M} \mathrm{\textrm {min } ^ { - 1 } )}\right.$ \\
\hline Free enzyme & 0.288 & 89.7 \\
Immobilized enzyme & 1.458 & 14.2
\end{tabular}

increase of the amount of $\mathrm{H}_{2} \mathrm{O}_{2}$. All the results were depicted as Fig. 7. In the beginning, the dye removal increased with increasing $\mathrm{H}_{2} \mathrm{O}_{2}$ amount because of insufficient of enzyme to dispose quantitative dye. But after the peak, continuous adding $\mathrm{H}_{2} \mathrm{O}_{2}$, the dye removal decreased instead, the reason may be that overmuch $\mathrm{H}_{2} \mathrm{O}_{2}$ influenced $\mathrm{pH}$ of the whole system.

3.5.3 Effect of enzyme amount. Enzyme amount also plays an important role in the process of degrading AO20 solution. Optimal enzyme amount keeps the reaction at high rate and make the degradation economical. To obtain this parameter of

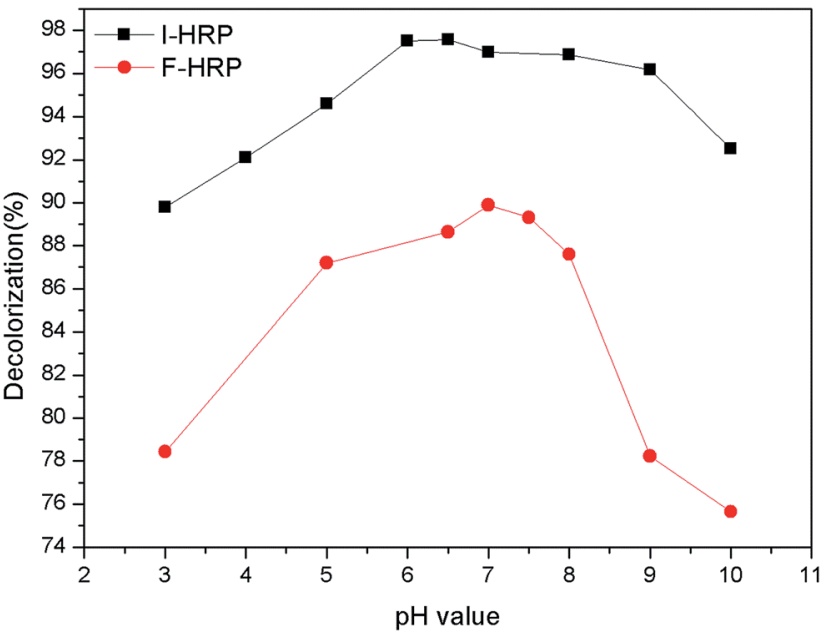

Fig. 6 Effects of pH on both F-HRP and I-HRP.

optimal enzyme amount, experiments were conducted by keeping the dye concentration, $\mathrm{H}_{2} \mathrm{O}_{2}$ amount, $\mathrm{pH}$ value and temperature of system at optimum along with other physical conditions as constant changing enzyme amount or PAN-beads amount so that any variation formed was a function of enzyme amount. We found that if the system merely with $\mathrm{H}_{2} \mathrm{O}_{2}$ didn't contain enzyme (both free and immobilized enzyme), the absorption value didn't change after experiment. For F-HRP the range of enzyme amount were from $1 \mu \mathrm{g}$ to $100 \mu \mathrm{g}$ and for I-HRP the range of enzyme amount were from $0.2 \mathrm{mg}$ to $8 \mathrm{mg}$. It's clear from Fig. 8 that $50 \mu \mathrm{g}$ free enzyme can reach its peak and $6 \mathrm{mg} \mathrm{I-}$ HRP are optimum, the reason could be that the activity of I-HRP was much lower than the original one. When free enzyme dosage or immobilized enzyme amount was maximum, increase of the amount could not increase the efficiency of dye removal.

3.5.4 Effect of contact time. The experiment of contact time was performed to determine the optimum time to dispose dye solution. The results were recorded in this case (Fig. 9). For F-

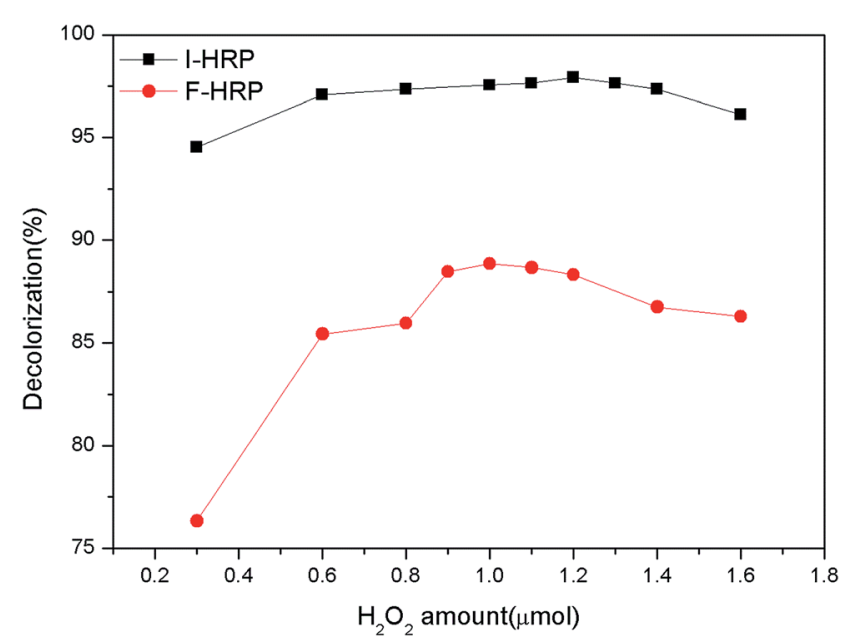

Fig. 7 Effects of $\mathrm{H}_{2} \mathrm{O}_{2}$ amount on both F-HRP and I-HRP. 


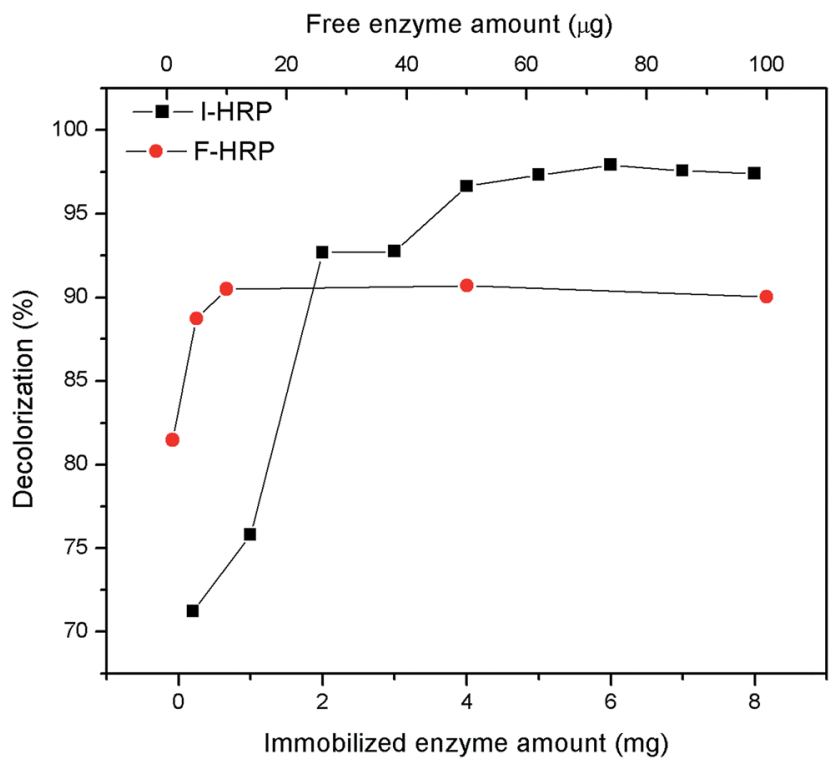

Fig. 8 Effects of free enzyme dose and PAN-beads on F-HRP and IHRP respectively.

HRP, it's apparent that the first 10 min of contact time was very important as almost 96\% decolorization was monitored in this period. After that period the rate of decolorization slowed down and finally achieved stability (about 88\%) until $40 \mathrm{~min}$. Compared to F-HRP, decolorization of AO20 treated by I-HRP achieved equilibrium more slowly and percent decolorization kept constant at $90 \mathrm{~min}$.

3.5.5 Effect of temperature. Temperature is also an important parameter governing the activity of enzymes. Temperature can provide more energy which is available to speed up the reaction rate so that the increase of temperature leads the increase of enzyme activity until an optimum temperature value arrives at which the enzyme shows maximum activity. But after that, further increase of temperature decreased enzyme activity due to denaturation of enzyme which

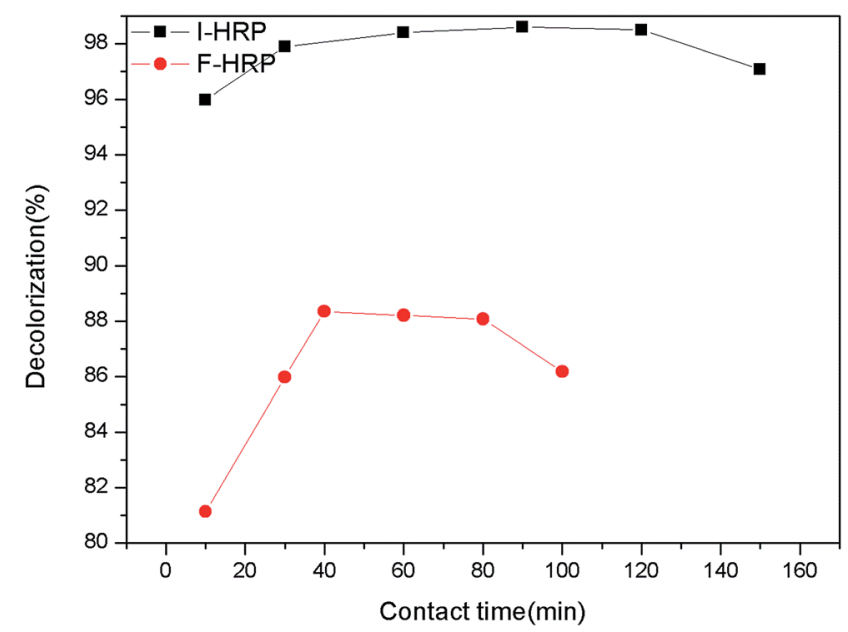

Fig. 9 Effects of contact time on both F-HRP and I-HRP.

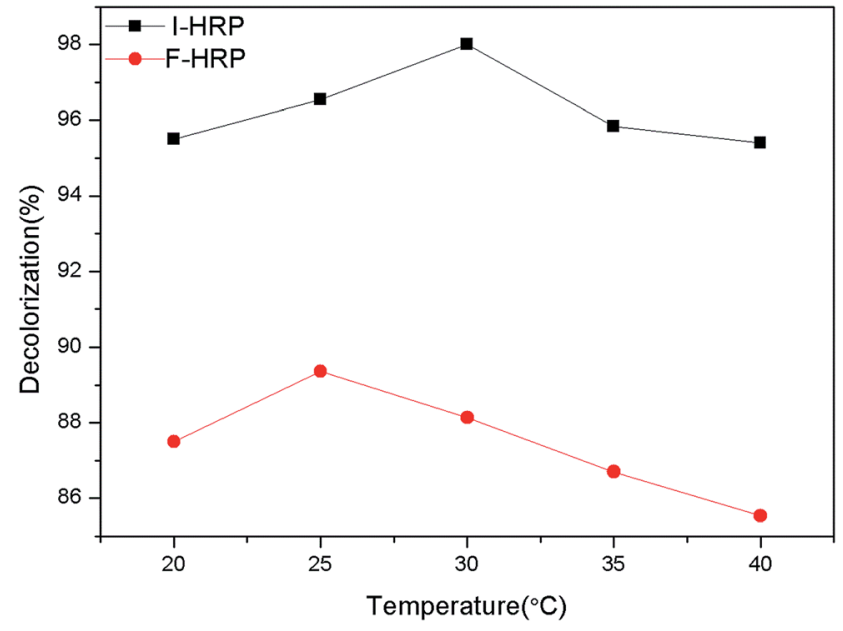

Fig. 10 Effects of temperature on both F-HRP and I-HRP.

cause changes in active site that will no longer accept the substrate. ${ }^{46}$ Thus, the effects of temperature on percent decolorization of AO20 mediated by both F-HRP and I-HRP were studied and the results are summarized. As we can see in Fig. 10, temperature plays a momentous role in the process of decolorization. $25{ }^{\circ} \mathrm{C}$ is optimum temperature for F-HRP and $30^{\circ} \mathrm{C}$ is the best temperature for I-HRP, and compared to I-HRP, the further increase of temperature makes percent decolorization using F-HRP decline more quickly, so F-HRP is more sensitive than I-HRP.

3.5.6 Decolourization of different concentration of $\mathrm{AO20}$ by immobilized horseradish peroxidase. Through abovementioned study, decolourization of $50 \mathrm{mg} \mathrm{L^{-1 }}$ of $\mathrm{AO} 20$ by immobilized horseradish peroxidase was effective, so effects of decoloration of higher concentrations of applied dye needed to be studied further. The experiment was conducted under optimum conditions except for dye concentration among 50$300 \mathrm{mg} \mathrm{L}^{-1}$ of underproof dye. The results were depicted as Fig. 11, from which we can see that percent decoloration

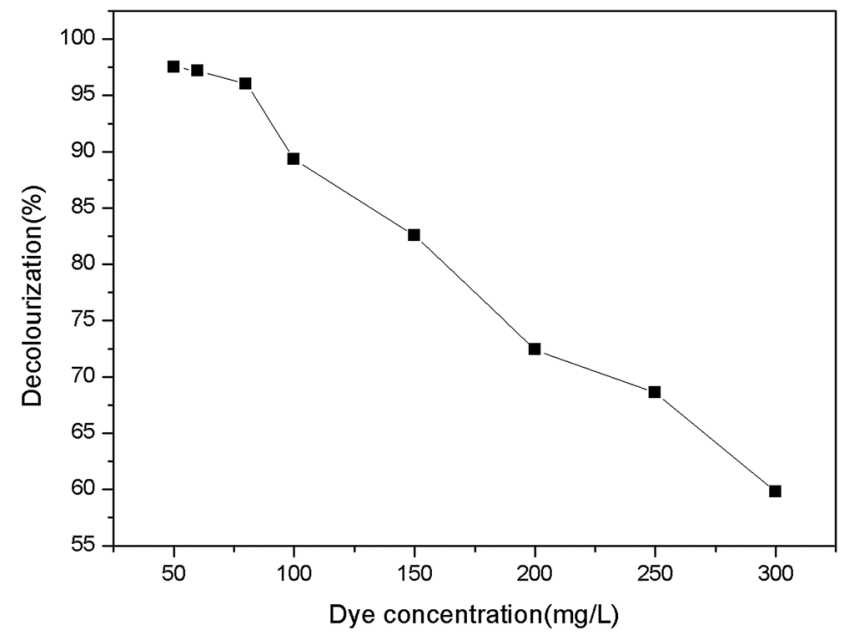

Fig. 11 Effect of dye concentration on immobilized horseradish peroxidase. 


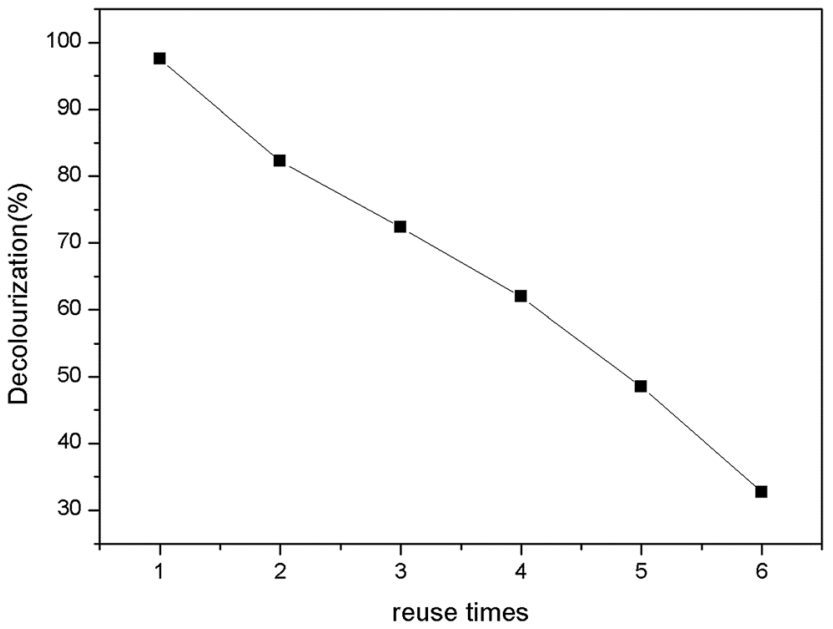

Fig. 12 Reusability of immobilized horseradish peroxidase.

decreased with increase of dye concentration and at the concentration of $300 \mathrm{mg} \mathrm{L}^{-1}$ there is still about $60 \%$ decoloration. This indicates that immobilized horseradish peroxidase has potential among a wide range of concentrations of $\mathrm{AO} 20$.

\subsection{Reusability of immobilized horseradish peroxidase}

The reusability can offer advantages and economy during practical process. The reusability was observed by assessing the percent decolorization of immobilized enzyme under same conditions after successive several times. ${ }^{47}$ After each recycle, the same enzyme immobilized PAN particles were washed with phosphate buffer $(0.1 \mathrm{M}, \mathrm{pH} 7.0)$ to remove any residual reactant within the enzyme-support system. The results were summarized as Fig. 12. The percent decolorization decreased with increase of recycle times. The immobilized beads still decreased $50 \%$ chromaticity up to 4 times recycle. In this work, there was $\sim 30 \%$ decolorization after 6 times reuse.

\subsection{Cytotoxicity analysis}

L02 cell line is a kind of immortalized human normal hepatocytes which possess similar biological properties to normal human hepatocytes in vivo and is an ideal cell model for studying cell toxicity. ${ }^{48}$ These cells have been widely used in studying liver cancer, genotoxicity, apoptosis and cytotoxicity in vitro study. ${ }^{49,50}$ MTT is a kind of assay which has been utilized in many study of cellular response to a toxicant. ${ }^{51}$ Cell toxicity is expressed as percentage cell viability which is indicated by value of optical density (OD) at $570 \mathrm{~nm}$, because formazan belonging to living cells is absorbed at $570 \mathrm{~nm}$ on a multiscan spectrum. ${ }^{52}$ The results were presented in Fig. 13. According to the Fig. 9, the amounts of those cells cultivated in normal culture containing different concentrations of dye solution $\left(150 \mathrm{mg} \mathrm{L}^{-1}\right.$, $225 \mathrm{mg} \mathrm{L}^{-1}, 300 \mathrm{mg} \mathrm{L}^{-1}$ ) untreated with enzyme increased by $27.96 \%, 41.52 \%, 56.36 \%$ respectively after four-day culture, which was different from previous reports, but this couldn't indicate that this kind of dye was harmless to human cells

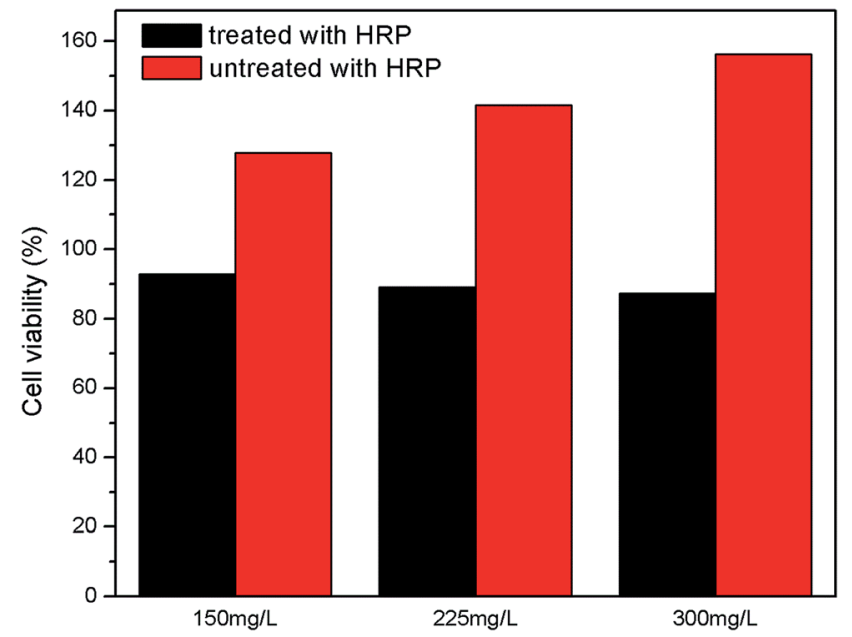

Fig. 13 Cytotoxicity test of treated and untreated $\mathrm{AO} 20$ solution.

because cell proliferation in the experiment was faster than control set. So there were reasons to doubt that the dye tended to induce malignant cellular proliferation, of course this conjecture needed further study. ${ }^{53}$ As for dye solutions treated with enzyme, the amounts of those cells cultivated with different concentrations of treated solutions decreased by small range for no more than $14 \%$, which was comparable to the result reported by K. Klemola and his co-workers. ${ }^{54}$

\section{Conclusion}

In the present work, the preparation and application of immobilized horseradish peroxidase on the PAN-based beads for AO20 removal from aqueous solution was investigated. Horseradish peroxidase was designed to be immobilized onto PAN-beads by crosslinking with glutaraldehyde accompanying with immobilized amounts of $10 \mathrm{mg} \mathrm{g}_{\text {enzyme }}{ }^{-1}$ and retention activity of $67 \%$. The performance of AO20 decolourization was found to be dependent on some factors that were $\mathrm{pH}$ values, $\mathrm{H}_{2} \mathrm{O}_{2}$ amounts, enzyme amounts and temperature, and the optimum conditions were obtained in this study. In addition, reusability experiment showed that the immobilized beads can be used up to three cycles remaining higher percentage decolourization of about $90 \%$, which provided a cost-efficient advantage for large-scale applications. Cell toxicity was also studied in this work, and the results indicated that the toxicity of metabolites of $\mathrm{AO} 20$ was acceptable compared to control group. In conclusion, this study provided a feasible potential method for economic, continuous and relatively safe disposal of azo dyes.

\section{References}

1 G. Palmieri, G. Cennamo and G. Sannia, Enzyme Microb. Technol., 2005, 36, 17-27.

2 K. Selvam, K. Swaminathan and K. S. Chae, Bioresour. Technol., 2003, 88, 115-119. 
3 S. Sandhya, in Biodegradation of Azo Dyes, ed. H. Atacag Erkurt, Springer, Berlin, 2010, pp. 39-57.

4 K. Golka, S. Kopps and Z. W. Myslak, Toxicol. Lett., 2004, 151, 203.

5 A. Gnanamani, M. Bhaskar, R. Ganga, G. Sekaran and S. Sadulla, Chemosphere, 2004, 56, 833.

$6 \mathrm{~J}$. Binkley and A. Kandelbauer, in Textile Processing with Enzymes, ed. A. Cavaco-Paulo and G. M. Guebitz, CRC Press, Boca Raton, 2003, pp. 199-221.

7 C. O'Neill, F. Hawkes, D. Hawkes, N. Lourenco, H. Pinheiro and W. Delee, J. Chem. Technol. Biotechnol., 1999, 74, 10091018.

8 H. Moawad, W. M. Abd El-Rahim and M. Khalafallah, J. Basic Microbiol., 2003, 43, 218-229.

9 G. T. Güyera, K. Nadeemb and N. Dizgec, J. Cleaner Prod., 2016, 139, 488-494.

10 J. Li, Y. Du, B. Deng, K. M. Zhu and H. Zhang, Environ. Sci. Pollut. Res., 2017, 24, 4932-4941.

11 T. Robinson, G. McMullan, R. Marchant and P. Nigam, Bioresour. Technol., 2001, 77, 247-255.

12 S. H. Lin and M. L. Chen, Water Res., 1997, 31, 868-876.

13 H. Zhang, J. H. Zhang, C. Y. Zhang, F. Liu and D. B. Zhang, Ultrason. Sonochem., 2009, 16, 325-330.

14 E. V. C. Rosa, E. L. Simionatto, M. M. Sierra, S. L. Bertoli and C. M. Radetski, Environ. Toxicol. Chem., 2001, 20, 839-845.

15 M. Hassan, W. M. Abd and M. Khalafallah, J. Basic Microbiol., 2003, 43, 218-229.

16 C. Wang, A. Yediler, D. Lienert, Z. Wang and A. Kettrup, Chemosphere, 2002, 46, 339-344.

17 S. M. A. G. U. De Souza, E. Forgiarini and A. A. U. De Souza, J. Hazard. Mater., 2007, 147, 1073-1078.

18 I. Khouni, B. Marrot, P. Moulin and A. R. Ben, Desalination, 2011, 268, 27-37.

19 Q. Husain, Crit. Rev. Biotechnol., 2006, 26, 201-221.

20 T. S. Shaffiqu, J. J. Roy, R. A. Nair and T. E. Abraham, Appl. Biochem. Biotechnol., 2002, 102, 315-326.

21 H. Qayyum, H. Maroof and K. Yasha, Crit. Rev. Biotechnol., 2009, 29, 94.

22 E. Torres, I. Bustos-Jaimes and S. Le Borgne, Appl. Catal., B, 2003, 46, 1.

23 C. Regalado, B. E. García-Almendárez and M. A. DuarteVázquez, Phytochem. Rev., 2004, 3, 243.

24 K. G. Welinder, Curr. Opin. Struct. Biol., 1992, 2, 388-393.

25 M. Bilal, H. M. N. Iqbal, S. Z. H. Shah, H. Hu, W. Wang and X. H. Zhang, J. Environ. Manage., 2016, 183, 836-842.

26 M. R. Silva, L. R. Vasconcelos, C. Russo, E. Scio and V. S. Ferreira-Leitao, Enzyme Res., 2010, 2010, 703824703831.

27 H. Zhang, S. Zhang, F. He, X. Qin, X. Y. Zhang and Y. Yang, J. Hazard. Mater., 2016, 320, 265-277.

28 F. Zheng, B. K. Cui, X. J. Wu, G. Meng, H. X. Liu and J. Si, Int. Biodeterior. Biodegrad., 2016, 110, 69-78.
29 L. Hassani, B. Ranjbar, K. Khajeh, H. N. Manesh, M. N. Manesh and M. Sadeghi, Enzyme Microb. Technol., 2006, 38, 118-125.

30 J. Z. Liu, T. L. Wang and L. N. Ji, J. Mol. Catal. B: Enzym., 2006, 41, 81-86.

31 N. C. Veitch, Phytochemistry, 2004, 65, 249-259.

32 E. Kalaiarasan and T. Palvannan, Clean: Soil, Air, Water, 2015, 43, 846-856.

33 G. Bayramoglu and M. Y. Arica, J. Hazard. Mater., 2008, 156, 148-155.

34 M. Celebi, M. Altikatoglu, Z. M. Akdeste and H. Yildrim, J. Biochem., 2012, 37, 200-206.

35 S. Khanahmadi, F. Yusof, A. Amid, S. S. Mahmod and M. K. Mahat, J. Biotechnol., 2015, 202, 153-161.

36 P. Sathishkumar, J. C. Chae, A. R. Unnithan, T. Palvannan, H. Y. Kim, K. Lee and J. M. Kamala-Kannana, Enzyme Microb. Technol., 2012, 51, 113-118.

37 M. Fernandez-Fernandez, M. A. Sanroman and D. Moldes, Biotechnol. Adv., 2013, 31, 1808-1825.

38 A. Sadighi and M. A. Faramarzi, J. Taiwan Inst. Chem. Eng., 2013, 44, 156-162.

39 S. C. Nigma, I. F. Tsao, A. Sakoda and H. Y. Wang, Biotechnol. Tech., 1988, 2, 271-276.

40 Z. Wang, Z. L. Chen, J. Chang, J. M. Shen, J. Kang and Q. Chen, Chem. Eng. J., 2015, 262, 904-912.

41 S. F. Li, J. P. Chen and W. T. Wu, J. Mol. Catal. B: Enzym., 2007, 47, 117-124.

42 M. M. Bradford, Anal. Biochem., 1976, 72, 248-254.

43 F. Anjum, V. Rishi and F. Ahmad, Biochim. Biophys. Acta, 2000, 1476, 75-84.

44 H. U. Bergmeyer, Methods of Enzymatic Analysis, Academic Press, New York, 2nd edn, 1974, vol. 1, p. 495.

45 Z. Wang, Z. L. Chen, J. Chang, J. M. Shen, J. Kang and Q. Chen, Chem. Eng. J., 2015, 262, 904-912.

46 M. L. Shuler and F. Kargi, Bioprocess Engineering-Basic Concepts, Prentice Hall PTR, Englewood Cliffs, NJ, 1992, pp. 58-102.

47 M. Bilal, M. Asgher and B. Asgher, Chem. Cent. J., 2015, 9, 47.

48 X. M. Huang, C. Chen, Y. Shang, Y. F. Zhong, G. F. Ren, Z. Q. Yu and J. An, Chemosphere, 2016, 161, 251-258.

49 C. S. Dai, D. W. Li, L. J. Gong, X. L. Xiao and S. S. Tang, Molecules, 2016, 21, 106.

50 G. P. Lv, L. Z. Menga, D. Q. Han, H. Y. Li, J. Zhao and S. P. Li, J. Pharm. Biomed. Anal., 2015, 109, 105-111.

51 M. V. Berridge, P. M. Herst and A. S. Tan, Biotechnol. Annu. Rev., 2005, 11, 127-152.

52 R. F. Hussain, A. M. E. Nouri and R. T. D. Oliver, J. Immunol. Methods, 1993, 160, 89-96.

53 C. Chen, Z. H. Lu, J. Yang, W. C. Hao, Y. J. Qin and H. Y. Wang, Cancer Med., 2016, 5, 3489-3499.

54 K. Klemola, J. Pearson and P. Lindstrom-Seppa, Autex Res. J., 2007, 7, 217-223. 